\title{
QCM Temelli Homosistein Nanobiyosensörünün Gerçek Zamanlı Tayin Sisteminde Optimizasyonu
}

\author{
Fatma Ayhan* \\ Muğla Sitkı Koçman University, Faculty of Science, Department of Chemistry, Biochemistry Division, Biochemistry\&Biomaterials Research Group (BIOMATREG), \\ Muğla, Turkey (ORCID: 0000-0003-2220-4496), fayhan@mu.edu.tr
}

(İlk Geliş Tarihi 19 Ağustos 2021 ve Kabul Tarihi 28 Kasım 2021)

(DOI: 10.31590 /ejosat.983841)

ATIF/REFERENCE: Ayhan, F., (2021). Homosistein Nanobiyosensörünün Geliştirilmesi ve Sürekli Akış Sisteminde Kullanımının Optimizasyonu, Avrupa Bilim ve Teknoloji Dergisi, (27), 1095-1104.

$\ddot{\mathbf{O z}}$

Metiyonin amino asitinden türeyen bir amino asit olan homosistein, damar hastalıkları için önemli bir risk faktörü olduğundan hızlı ve ucuz bir yöntemle tayini son yıllarda üzerinde çalışılan ve gittikçe artan öneme sahip bir araştırma konusudur. Sunulan bu araştırma kapsamında, Kuartz Kristal mikrobalans (QCM) yöntemi kullanılarak homosisteinin gerçek zamanlı tayini yapılmıştır. QCM tekniği özellikle nano düzeylerde bazı maddelerin varlığının nicel ve/veya nitel olarak tespitinde kullanılmaktadır. Kristalin elektrodunun yüzeyine özgül olarak immobilize edilen tanıyıcı maddenin hedef maddeyi yakaladığı mikrogravimetrik tayin prensibine dayanmaktadır. Yapılan çalışmada, kuartz kristal mikroterazi (QCM) tekniği ile homosisteinin sıvı ortamda ve sürekli akış sisteminde gerçek zamanlı bir yöntemle tayini mevcut yöntemlere göre daha hızlı olarak gerçekleştirilmiştir. Bu amaçla çalışmanın ilk aşamasında altın $(\mathrm{Au})$ elektrotlu kristal yüzeylerinin modifikasyonu gerçekleştirilmiştir. Yüzey yıkama ve aktivasyon işleminden sonra yüzeye sisteamin ve daha bifonksiyonel bir yapıda olan glutaraldehid (GA) bağlanması gerçekleştirilmiştir. GA bağlanmış yüzeylere homosisteini özgül olarak tanıyan biyolojik ligand Bovin Serum Albumin (BSA) immobilize edilmiştir. En uygun BSA derişimi olarak $0,1 \mathrm{mg} / \mathrm{ml}$ seçilmiştir. Bu BSA yüzey derişimi ile yapılan homosistein bağlanma deneyleri ile $0,01-0,5 \mu \mathrm{M}$ aralığında homosistein kalibrasyonu gerçekleştirilmiş ve en düşük tayin edilebilir değer olarak $0,01 \mu \mathrm{M}$ yani $10 \mathrm{nM}$ düzeyinde homosistein değeri belirlenmiştir. Böylece bu önerilen sistemle nanodüzeyde homosistein tayini yapılabilmiştir. Çalışmanın ikinci aşamasında gerçek zamanlı (real-time) homosistein ölçümleri ile yöntemin verimliliği, tekrarlanabilirliği ve tayin edilebilecek en düşük homosistein değerinin tespit edilmesi sağlanmıştır. Sonuçta damar hastalıklarının önemli bir belirteci olan homosisteinin tayininde geliştirilen sistemin yeni bir yöntem olarak kullanım potansiyeli olduğu düşünülmektedir.

Anahtar Kelimeler: Kuartz kristal mikroterazi (QCM), Homosistein, Yüzey modifikasyonu, Gerçek zamanlı tayin, Optimizasyon.

\section{Optimization of QCM-Based Homocysteine Nanobiosensor in Real- Time Detection System}

\begin{abstract}
Homocysteine, which is a methionine amino acid derived amino acid is an important risk factor for vascular deseases so, its dedection by a rapid and cheap method is under investigation and is an research theme with gradually increasing importance. In the scope of the presented study, the real time detection of homocysteine by using Quartz Crystal Microbalance (QCM) method was performed. QCM technique is used for quantitative and/or qualitative determination of some materials especially which are present in nanoscale levels. The analysis lies on the microgravimetric analysis where the specific compound attached to the surface of crystal capture the target compound. The detection of homocysteine with QCM technique in liquid and continuous flow system was achieved in a real time method faster than other available methods. For the purpose, the modification of gold (Au) crystal surfaces was performed in the first part of the study. Cystamine was immobilized after surface washing and activation process and then binding of bifunctional glutaraldehyde (GA) was achieved. Homocysteine specific recognizing biological ligand Bovine Serum Albumin (BSA) was immobilized to glutaraldehyde coupled surfaces. The most convinient BSA concentration was selected as $0,1 \mathrm{mg} / \mathrm{ml}$. and homocysteine coupling values was determined and the calibration of homocystein was achieved. Homocysteine calibration curve was realized by homocysteine coupling experiments with this BSA surface concentration and the minimum detection limit was found as $0,01 \mu \mathrm{M}$ which coincide to $10 \mathrm{nM}$ homocysteine value. Hence, homocysteine was detected in nano level in the proposed system. In the second part of the research, productivity, reproducibility, and minimum detection limit of the method was determined by the experiments of real-time detection of homocystein. Thus, it is thought that the system developed for the determination of homocysteine, which is an important marker of vascular diseases, has the potential to be used as a new method.
\end{abstract}

Keywords: Quartz crystal microbalance (QCM), Homocysteine, Surface modification, Real-time detection, Optimization.

* Sorumlu Yazar: fayhan@mu.edu.tr 


\section{Giriş}

Nanoteknoloji, Bilim ve Teknolojideki yeni hedeflerin en önemlilerinden biridir. Nanoteknoloji, boyutları $100 \mathrm{~nm}$ ve daha küçük olan yapıların oluşturulması ve bu şekilde özellikleri önemli derecede değişebilen çeşitli materyallerin sentezlenmesini sağlar (Tüylek, 2021). Bu materyaller ile değişik uygulamalar için daha üstün özelliklere sahip polimerik nanokompozitler veya dendrimeric biyosensor gibi uygulamalarda kullanımı tasarlanabilir (Matthews, 1998; Horst, 2020; Shende, 2020).

Homosistein, kükürt içeren ve metiyonin esas amino asitten türeyen bir amino asittir. Genetik ile diyetetik faktörler ve B kompleks vitaminleri (folat, B12, B6 gibi) Homosisteinin plazma düzeylerini kontrol ederler. Vitamin eksikliği hiper homosisteinemia'ya yol açan ana unsurdur ve düzensiz vitamin alımı, gastrointestinal sistemdeki absorbsiyon azalması, B6 ve B12 vitaminlerine ve folik asite ihtiyacın artması and ilaç etkileşimleri gibi nedenlerle de ortaya çıkabilir. Yüksek plazma homosistein değerleri $(>12 \mu \mathrm{mol} / \mathrm{L})$ sitotoksik olarak düşünülmektedir ve genel nüfusun yüzde 5-10'unda ve damar bozukluğu olan hastaların \% 40'1nda rastlanmaktadır. Son yıllarda, homosisteinin serebral, koroner ve periferik damarları etkileyen aterosklerotik damar hastalıkların bağımsız bir risk faktörü olduğu gösterilmiştir. Varılan ortak görüş odur ki; damar bozukluğu olanlar, kalp-damar bozukluğu riski taşıyanlar, vitamin eksikliği olanlar ve 50 yaşın üzerindekilerin homosistein değerlerinin bilinmesi gerekmektedir.

Serum/plazmada var olan toplam homosistein tayini için çeşitli yöntemler geliştirilmiştir. Bunların başlıca ve en çok kullanılan yöntemlerden biri yüksek basınçlı sıvı kromatografisi (HPLC) metodudur (Vester, 1991). Fluoresan ajanın kullanıldığ yöntemde fluoresan dedektörlü HPLC sistemine ihtiyaç vardır ve fluoresan parçalanma ürünleri, gradient ayırmaya ihtiyaç duyulması, yüksek sıcaklıkta türevlendirme ve fluorojenik ajan olan 7-fluorobenzo-2-okza-1,3-diazol-4-sulfonat (SBD)'ın 1şığa hassaslığı, zaman ve tecrübeli eleman gerektirmesi gibi zorluk ve dezavantajları vardır. Elektrokimyasal ve kütle dedektörlü HPLC

sistemlerinde de dedektör kararlılığı ve pahalı olmaları gibi dezavantajlarla karşılaşılmaktadır. Geliştirilen immunoassay metodlarda ise karşılaşılan en büyük sorun reaktiflerin pahalı olmasıdır (Imai, 1987; Ubbink, 2000). Serum/plazma toplam homosistein tayini için geliştirilen bir otoanalizör, kemilüminesan enzim immünoassay yöntemini kullanmaktadır (Frantzen, 1998). Yöntemde enzimle muamele ve mikroplakaların muamelesi olmak üzere iki aşamadan oluşmaktadır. Altın nanopartikül/camsı karbon elektrodun yüzeyine Homosistein bağlayan aptamer aşılanarak aptasensör oluşturulmuş ve electrokimyasal olarak diferansiyel puls voltametrisinde homosistein sinyalleri alındığ rapor edilmiştir (Beitollahi, 2020). Anti-Homosistein antikorunun gümüş kristal yüzeyine immobilizasyonu ve QCM-temelli analiz ile homosisteinin tayin edilmiştir (Ayhan, 2020).

Serumdaki (plazma) homosisteinin önemli bir bölümü plazma proteinleri ile ağırlıklı olarak da albümin ile disülfid bağları aracılı̆̆ı ile birleşmiş olarak bulunmaktadır. Bu oran sağlıklı insan serumundaki (plazma) toplam homosisteinin 70'ini oluşturmaktadır (Ueland, 1993). Kandaki homosisteinin tayinin doğru yapılabilmesi için indirgeyici ajan varlığında disülfid bağlarının kırılması ile proteine bağlı homosisteinin açığa çıkarılması gerekmektedir (Refsum, 1989; Krijt, 2001).
Toplam homosisteine (tHcy) serbest ve proteine bağlı olmak üzere plazma/serumdaki tüm homosistein türlerinin toplamı olarak tanımlanmaktadır. Serum/plazmadaki toplam Hcy kobalamin veya folat eksikliği olan hastalarda önemli ölçüde artmaktadır ve sadece eksik vitamin ile takviye edildiğinde azalmaktadır. $\mathrm{Bu}$ nedenle toplam homosistein teşhis ve eksikliklerin takibi için gerekli olan bir değerdir ve geleneksel laboratuar analizlerinin zayıflı̆̆ını gidermede kullanılabilir. Ayrıca toplam homosistein erken kalp-damar bozuklukları için tehlike oluşturacak bağımsız bir etkendir. Bu bozukluklar sıradan hastane kimya laboratuarında toplam homosistein tayinini gerekli kılmaktadır (Ueland, 1993). Şiddetli homosistinuriya erken kalpdamar bozukluklarına yol açmakta fakat az ve orta homosistinuriya veya homosistinemiyanın hasta sonuçları kesin olarak belirlenmemiştir. Şiddetli homosistinuriyaya neden olan en büyük sebep transülfürasyon yolunda sistatiyonin $\beta$-sintazın doğuştan olmaması veya tam etki göstermemesidir. Beslenme eksikliği veya düşük vitamin absorpsiyonu nedeni ile dokudaki kobalamin $(\mathrm{Cbl})$ ve folat eksikliği de homosistinemiyaya neden olabilir. Homosistein Cbl-bağlı metiyonin sintaz (hayvan dokularında yaygındır) ve hepatik betain: homosistein Smetiltransferaz ile metiyonine dönüştürülür (Jacobsen, 1989). Ayrıca böbrek yetmezliği, doğuştan bozukluk, psikiyatrik bozukluklar ve hamilelikte yaşanan zorlukların idaresinde homosistein ölçümleri önerilmiştir (Kellogg, 2005).

Günümüzde homosistein tayini analitik olarak çoğunlukla fluoresans, elektrokimyasal ve kütle dedektörlü yüksek basınçlı sıv1 kromatografisi, immünolojik teknikler gibi yöntemlerle gerçekleştirilmektedir. Bahsedilen yöntemler gerek ön işlem gerektirmeleri gerekse işlemlerin zahmetli olması, eğitimli elemana ihtiyaç duyulması ve cihazların pahalı olması gibi nedenlerle uygulamada zorluklarla karşılaşılmaktadır. Son yıllarda gelişen nano boyut teknolojisi sayesinde polimerik ve anorganik malzemeler önem kazanmıştır. Bu bağlamda altın veya gümüş elektrotlu piezo kristallerin resonans frekansından faydalanarak nano düzeyde nitel ve nicel analizler yapılabilmektedir.

\section{$\Delta f=-2.26 \times 10^{6} f^{2} \Delta m / A$}

Kristal üzerine ilave edilen kütle $(\Delta \mathrm{m})$, kristalin salınım frekansında kaymaya neden olur $(\Delta \mathrm{f})$, ki bu kayma ölçülebilirse kütle artışı yukarıdaki basit ifadeyle hesaplanabilir. Bu denklik ilk kez Sauerbery tarafından türetilmiş olup onun adıyla anılmaktadır (Sauerbrey, 1959; Bunde, 1998). Burada ölçülen ağırlık değişimleri ng seviyelerinde olduğundan bu sistem biyosensör uygulamalarına oldukça yatkındır ve uzunca bir süredir bu amaçla kullanılmakta ve çalışmalar devam etmektedir. Piezoelektrik kristallerin rezonans frekansının ölçülmesi için ticari olarak mevcut salınım ölçerler kullanılır. Pratik olarak kullanılan sistemlerde iki salınım devresi yer alır. Her iki devreye de takılı olan kristal benzer özelliklerdedir. Ancak birinin (ölçüm kristali) sensör olarak kullanılmak üzere yüzey modifikasyonu yapılmış (ligand takılmış) diğerine (referans kristal) ise hiçbir işlem uygulanmamıştır. Bu ikinci devre sıcaklık ve nem etkilerini ve ölçülecek madde dışında ortamda bulunan diğer maddelerin kristal ile özgül olmayan etkileşimi sonunda ortaya çıkacak girişimlerini en aza indirmek amacıyla kullanılmaktadır.

Kuartz kristal mikrobalans (Quartz Crystal Microbalance, QCM) farklı biyosensör uygulamalarında kullanılan yüksek frekanslı yüzeydeki değişimlere hassas bir yöntemdir (Marx, 2003). Sensör yüzeylerine adsorbe olan tabakaların rezonans frekansındaki $(\Delta f)$ değişimlerin görüntülenmesi temeline 
dayanmaktadır. Kuartz kristal mikrobalans (QCM) yöntemi uygun modifikasyon ile birçok organofosfor ve karbamat pestisid tayininde (Karousos, 2002), antijen veya antikor tanımlanmasında (Liu, 2004), suni yüzeylerde kan pıhtılaşma yoğunluğu ve immün komplement aktivasyonunun (Andersson, 2005) tespiti çalışmalarında kullanılmıştır. Kristal modifikasyonunda kullanılan yöntemlerden bazıları sistamine-glutaraldehit yöntemi (Lee, 2005), fiziksel adsorpsiyon, iki tiyoamin ile tiyolleme metodu ki burada sisteamin ve sistamin altın üzerine kimyasal sorpsiyon amaçlı kullanılmıştır. İki oksitlenmiş dekstran uzatma kolunun kullanımı gibi yöntemlerle anti-Human Serum albumin (HSA) immobilize edip HSA tayininde kullanarak karşılaştıran çalışmalar mevcuttur (Liu, 2001). Kuartz kristal mikroterazi sisteminin sıvıda veya akış sisteminde farklı araştırma ve uygulamaları mevcuttur (Liu, 2003, a; Lee, 2005; Zhang, 2008; Ozalp, 2015; Bereli, 2020; Y1lmaz, 2021).

Sürekli Sistemde ise Kuartz kristal mikroterazi sisteminin sıvıda veya akış sisteminde farklı araştırma ve uygulamaları mevcuttur. Çözeltide IgG ile histidin arasındaki ilişki kuartz kristal mikroterazi biyosensör ile gerçek zamanlı olarak tayin edilmiştir (Liu, 2003,a,). Çalışmada akış enjeksiyonlu çalışan bir sistemde yapılan yüzey modifikasyonları sonrasında kristal histidin çözeltisine daldırılmıştır ve IgG enjekte edilerek frekans değişimi incelenmiştir. Protein ve küçük moleküllü tıbbi kimyasallar arasındaki etkileşim kuartz kristal biyosensör ile gerçek zamanlı olarak gözlenmiştir (Tanaka, 2001; Liu, 2003,b). Sıvı ortamda bir viral hastalık olan BEF'nin virüsünün tespiti akış tipli kuartz kristal mikroterazi immünosensör ile araştırılmıştır (Lee, 2005). Heparin ve antitropbin III arasındaki etkileşim kuartz kristal mikroterazi elektrod yüzeyi poli(glisidil metakrilat) film ile kaplandıktan sonra incelenmiştir (Zhang, 2004). Heparin immobilizasyonu sonrası antitrombin III etkileşimi akış enjeksiyonu sonrası frekans değişimi ile incelenmiştir. Yine aynı iki molekül arasındaki ilişki kristal yüzeyinde nanoaltın oluşumu in situ büyüme izlendikten sonra incelenmiştir (Zhang, 2008). Vibrio parahaemolyticus'un oligonükleotitlerinden tayini için QCM kristal yüzeyi plazma modifikasyonu ile hexametildisilazan kullanılarak modifiye edilmiştir (Chen, 2007). Böylece oluşturulan arayüzey ile altın nanopartiküllerin oligonükleotedlerle bağlanması sağlanmıştır. İnsan serum albumin (HSA) üzerine ilaçların bağlanma bölgelerini belirlemek amacı ile basit ve etkile bir yöntem geliştirilmiştir. Bilirubinin bağımsız olarak bağlanması veya yarışmalı yer değiştirmesinden yararlanılarak akış enjeksiyonlu analiz-kuartz kristal mikroterazi (FIA-QCM) kullanılmıştır. Bağımsız ve yarışmalı bağlanma gerçek zamanlı olarak görüntülenmiştir. Sonuçlar ilaç ve HSA arasındaki hareketli etkileşimi görüntülemek için FIA-QCM'in doğru bir yaklaşım olabileceğini göstermiştir. Üstelik işaretlemeye gerek olmadan ilaç bağlanma bölgelerini de gerçek zamanlı olarak belirlemek mümkün olabilecektir (Zhang, 2008). Son yıllarda yapılan başka bir çalışmada genetiği değiştirilmiş organizmaların (GMO) görüntülenmesi hedeflenmiştir. Bu amaçla AcMV 35S promoter diziliminin hibridizasyonunun tayini için kütleye hassas kuartz kristal mikroterazi (QCM)-temelli DNA biyoalgılayıcı geliştirilmiştir. Geliştirilen QCM temelli DNA algılayıcı GMO’nın görüntülenmesi için gerçek zamanlı, işaretleme yapmadan ve doğrudan tespiti için umut verici sonuçlar elde edilmiştir (Karamollaoğlu, 2009). Kuartz kristal mikroterizi ve elektrokimyasal impedans spektroskopi yöntemleri birleştirilerek altın ve platin elektrodlar üzerine BSA adsorpsiyonu incelenmiş ve farklı $\mathrm{pH}$ değerlerinde elektrokimyasal ve yüzey yapılarının değiştiği tespit edilmiştir (Xie, 2003).
Bu araştırma kapsamında, sürekli sistem akış hücreli Kuartz Kristal mikrobalans (QCM) yöntemi kullanılarak homosistein tayini gerçekleştirilmiştir. Proje kapsamında önerilen çalışmada altın piezo kristal elektrodları yüzeylerine yapılacak temizleme, modifikasyon ve biyolojik molekül immobilizasyonu sonrası sıvı akış ortamında ölçüm yapılarak klinik laboratuar koşullarına daha uygun bir ortamda analiz imkânı elde edilmiştir. Çalışmada ilk aşamada quartz kristal yüzeylerinin modifikasyonu gerçekleştirilmiştir. $\mathrm{Bu}$ bağlamda altın $(\mathrm{Au})$ elektrodlu piezo kristaller kullanılmıştır. Yüzey yıkama işleminden sonra yüzeye sisteamin immobilizasyonu, daha sonra sisteamin üzerine bifonksiyonel glutaraldehid (GA) bağlanması gerçekleştirilmiştir. GA bağlanmış yüzeylere homosistein ile disülfit bağları yapan bir molekül olan albümin (BSA) bağlanması sağlanarak kalibrasyon doğrusunun oluşturulmasından sonra yöntemin verimliliği ve tekrarlanabilirliği tespit edilmiştir. Ayrıca tayin edilebilecek en düşük homosistein değeri belirlenerek yöntemin kullanılabileceği en düşük alt sınır değeri tespit edilmiştir. Böylece homosisteinin hızlı, daha ucuz ve ön işlemleri azaltılmış olarak aynı elektrodun tekrarlanarak kullanılmasına olanak verecek bir yöntemle tayini amaçlanmıştır.

\section{Materyal ve Metot}

Araştırmada kullanılan kimyasal maddeler ticari kaynaklardan temin edilmiştir. $\mathrm{H}_{2} \mathrm{SO}_{4}: \% 30 \mathrm{H}_{2} \mathrm{O}_{2}$, sisteamin, glutaraldehit, BSA, Homosistein, glisin Merck'ten satın alınmıştır. Diğer bütün kimyasal maddeler analitik saflıktadır. QCM200 Kuartz Kristal Mikroterazi sistemi ve $5 \mathrm{MHz}$ AT kesimli 1“ altın QCM çipler SRS ${ }^{\circledR}$ den satın alınmıştır. Deneysel çalışmaların bütün aşamalarında Merck Millipore ultrapure (type 1) Direct-Q ${ }^{\circledR} 8$ UV ile saflaştırılmış su kullanılmıştır.

\subsection{Yüzey modifikasyon işlemleri}

\section{Biyolojik molekül immobilizasyonu öncesi işlemler}

Çalışma kapsamında piezo kristal yüzeyine Homosistein tayini için tanıyıcı ligand kimyasal olarak tutuklanmıştır. Homosisteini tanıyacak biyolojik molekülün bağlanması öncesinde yapılan ön işlemler aşağıdaki gibi gerçekleştirilmiş ve Şekil 1'de şematik olarak verilmiştir (Ayhan, 2014).

\subsubsection{Yüzey temizliği}

QCM'in altın elektrodun iki yüzeyine sıcak Piranha çözeltisi (derişik $\mathrm{H}_{2} \mathrm{SO}_{4}$ : \% $30 \mathrm{H}_{2} \mathrm{O}_{2}, 3: 1 \mathrm{v} / \mathrm{v}, 5 \mu \mathrm{l}$ ) eklenmiş ve 5 dak beklenmiştir. Distile su ile yıkanan kristal yüzeylerine aynı işlem tekrar uygulanmıştır. Tekrar distile su ile yıkanan yüzeyler etüvde $37^{\circ} \mathrm{C}$ 'de yaklaşık 30 dakika kurutulmuş elektrodun frekans değeri okunmuş ve başlangıç frekansı olarak kayıı edilmiştir (Herne, 1997; Liu, 2004; Lee, 2005).

\subsubsection{Sisteamin İmmobilizasyonu}

Kuartz kristallerin yüzey temizleme aşamasından sonra kristal yüzeylerine Sisteamin $\left(\mathrm{C}_{2} \mathrm{H}_{7} \mathrm{NS}\right)$ bağlanması gerçekleştirilmiştir. Sisteamin molekülü bir tiyol $(\mathrm{SH})$ ve birde amin $\left(\mathrm{NH}_{2}\right)$ olmak üzere iki fonksiyonel uca sahip bifonksiyonel bir moleküldür. Yumuşak baz olan sisteamin molekülünün bu özelliğinden yararlanılarak tiyol ucundan, gene yumuşak asit olan Au kristal yüzeyinden tutturulmuş ve diğer amin ucu fonksiyonel olarak başka bağ için hazır tutulmuştur (Laibinis, 1991; Likogiani, 2006). Bu amaçla, $18 \mathrm{mM}$ derişimde sisteamin, fosfat tamponunda $\left(0,01 \mathrm{M} \mathrm{pH=7)}\left(\mathrm{Na}_{2} \mathrm{HPO}_{4} / \mathrm{NaH}_{2} \mathrm{PO}_{4}\right)\right.$ çözülmüştür. Kristaller 30 dakika süreyle elde edilen çözelti içinde karanlık ortamda etkileştirilmiş ve süre sonunda deiyonize suyla 15 dakika 
boyunca yıkanmıştır. Yıkama işleminden sonra kurutularak frekans değerleri ölçülmüştür.

\subsubsection{Glutaraldehit (GA) İmmobilizasyonu}

Sisteamin bağlı kuartz kristallerin üzerine uzatma kolu (spacer arm) takılması amacıyla yine bifonksiyonel özelliğe sahip olan gluteraldehit $\left(\mathrm{COH}\left(\mathrm{CH}_{2}\right)_{3} \mathrm{COH}\right)$ kullanılmıştır. Burada amaç sisteaminin serbest olan amin ucu ile gluteraldehitin aldehit uçlarının reaksiyona girmesi ve şift bazı reaksiyonu ile imin oluşumu ile bağlanmalarının sağlanmasıdır (Hou, 1991fl. Bunun için sisteamin bağlı kuartz kristaller $0,01 \quad \mathrm{M}$ sodyum tetraborat $/ \mathrm{HCl}$ tamponu ile

pH: 8.2 'de \% 3 (h/h) glutaraldehit ile etkileştirilmiştir. Kristaller reaksiyon ortamında 30 dakika süreyle tutulmuş ve süre sonunda ultra saf su ile 15 dakika boyunca yıkanmıștır. Yıkama işleminden sonra kurutularak frekans değerleri ölçülmüştür.

\subsection{Bovine Serum Albumin İmmobilizasyonu}

QCM sensor yüzeyinde oluşan tiyol ve aldehit oluşumu sağlandıktan sonra kristal oda sıcaklığında farklı derişimlerde BSA çözeltilerine ( $\mathrm{pH} 5$ fosfat tamponunda, (pI (BSA) 4.7)) daldırılarak 2 saat bekletilmiştir. BSA derişimi $0,1 \mathrm{mg} / \mathrm{mL}$ olacak şekilde ve önce PBS ile daha sonra da deiyonize su ile yıkanarak kurutulduktan sonra frekansı ölçülmüştür (Ayhan, 2014). Son aşamada açıkta kalan aktif bölgeleri kapatmak amacı ile QCM sensörü 30 dakika süre ile $100 \mathrm{mM}$ glisin ile etkileştirilmiş ve önce PBS ile daha sonra da deiyonize su ile yıkanarak yine kurutulduktan sonra frekans ölçülmüştür.

\subsection{Sürekli akış sisteminde Homosistein tayini}

Araştırma kapsamında tanıyıcı ligand tutuklanması aşamasından sonra homosistein tayini çalışmaları gerçekleştirilmiştir. Çalışma için homosistein $50 \mu \mathrm{mol} / \mathrm{L}$ stok çözeltisi ( $\mathrm{pH} 7.4,0,01 \mathrm{M}$ PBS) hazırlanarak deney aşamalarında bu çözeltiden seyreltmeler yapılarak deneyler gerçekleştirilmiştir. Homosistein çözeltisi kullanılmadığ 1 zaman $+4^{\circ} \mathrm{C}$ 'de bekletilmiş ve kullanım süresi bir hafta olacak şekilde çalışılmıştır. BSA immobilize edilmiş QCM sensör akış hücresine yerleştirildikten sonra 0.01 M PBS (pH 7.4) çözeltisini kullanarak $100 \mu \mathrm{L} /$ dak akış hızında sürekli sistemde belli derişimde homosistein içeren çözeltiden $100 \mu \mathrm{L}$ verilmiştir

Farklı derişimler için bağlanma eğrileri oluşturulmuştır. Her derişim için gözlenen frekans farkından yararlanılarak kalibrasyon doğrusu oluşturulmuştır. Hazırlanan farklı derişimler için de frekans farkları tespit edilmiştir. Gözlenen frekans farkı ile hazırlanan doğrudan yararlanarak derişim tespit edilmiştir. Böylece akış enjeksiyonlu sürekli sistemin verimliliği belirlenmiştir. Benzer şekilde belli derişimden iki kez tekrarlanarak tekrarlanabilirlik yüzdesi elde edilmiştir. Ayrıca tayin edilebilen en düşük homosistein derişimi belirlenmiştir. Gün içi ve günler arası tekrarlanabilirlik ölçümleri ile de yöntemin verimliliğinin belirlenmiştir. Bir bağlanma deneyinden sonra enjeksiyon vanasından $600 \mu \mathrm{l}$ glisine: $\mathrm{Cl}$ çözeltisi $(100 \mathrm{mmol} / \mathrm{L}$, $\mathrm{pH}$ 2.5) verilerek reseptör tabakadaki bağlı biyomolekülleri ve serbest bağlanma bölgeleri sonraki bağlanma için hazır hale getirilmiştir (Liu, 2003,a; Liu, 2004; Lee, 2005). Kullanılmadığı zaman kuartz kristaller $+4^{\circ} \mathrm{C}$ 'de bekletilmiştir. Deneyler oda sıcaklığında gerçekleştirilmiştir. Deneysel sonuçlar en az üç değerin ortalaması olarak verilmiştir. Ayrıca biyolojik molekül immobilizasyonu öncesi kristal homosistein ile etkileştirilerek özgül olmayan etkileşim olup olmadığı da incelenmişstir.
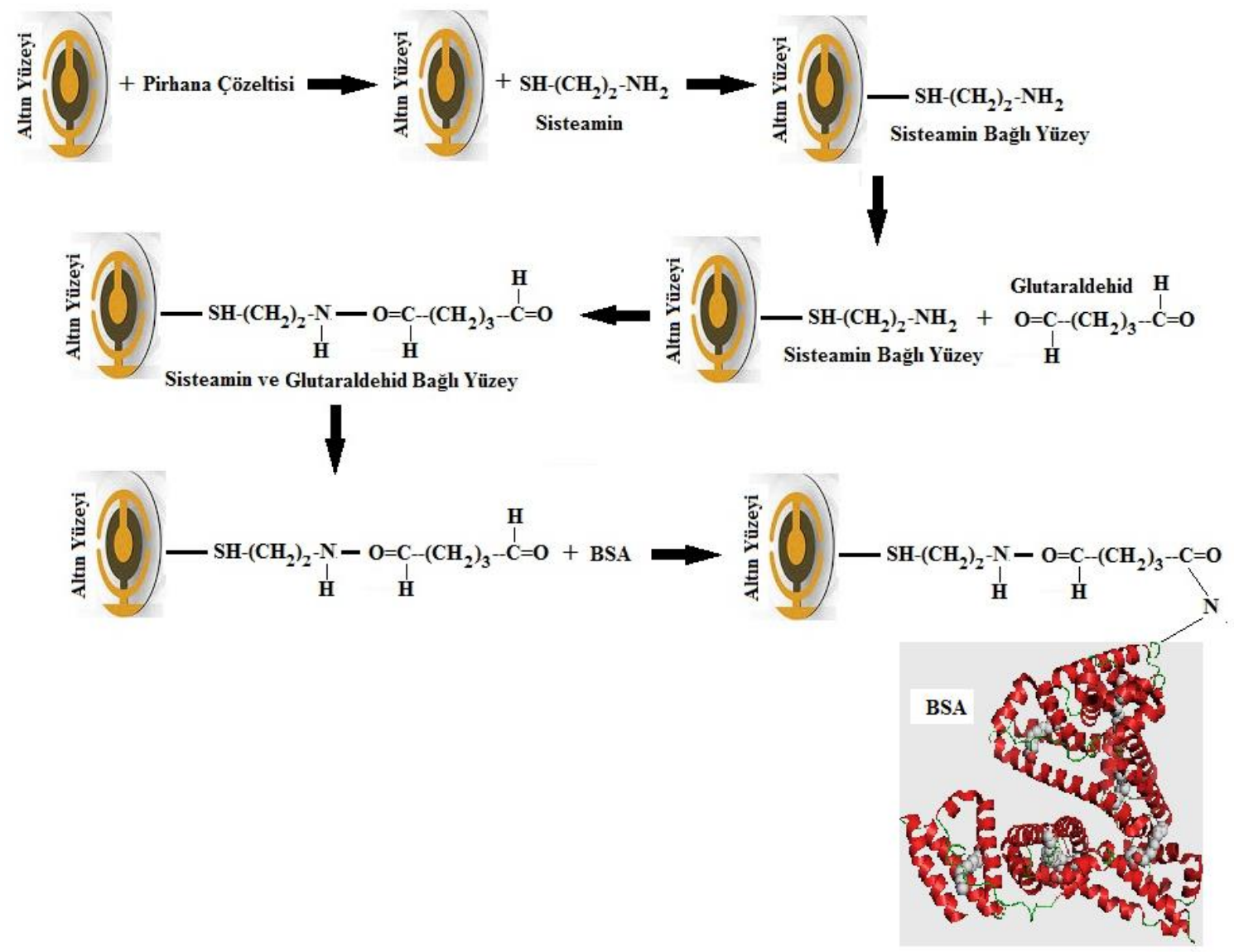


\section{Araştırma Sonuçları ve Tartışma}

\subsection{Biyolojik molekül immobilizasyonu}

Yüzey temizliği veya modifikasyonu aşamasında altın elektrodlu kristallerde yaklaşık $70 \pm 5 \mathrm{~Hz}$ 'lik frekans kaymaları gözlenmiştir. Bu aşamada yüzeylerin temizlendiği ve genellikle de hidrofilik özellik gösterdiği bilinmektedir. $\mathrm{Bu}$ durumun literatür ile de uyumlu olduğu görülmüştür (Ayhan, 2008). Sisteamin İmmobilizasyonu aşamasında ise $8 \pm 1 \mathrm{~Hz}$ aralığında frekans kaymaları bulunmuştur. Glutaraldehit (GA) İmmobilizasyonu kısmında Sisteamin immobilize kuartz kristallerin üzerine uzatma kolu (spacer arm) takılması amacıyla yine bifonksiyonel özelliğe sahip olan gluteraldehit $\left(\mathrm{COH}\left(\mathrm{CH}_{2}\right)_{3} \mathrm{COH}\right)$ kullanılmıştır. $\mathrm{Bu}$ aşamada ise yaklaşık ortalama $12 \pm 1 \mathrm{~Hz}$ frekans kayması gözlenmiştir. BSA bağlanması aşamasında ise $40 \pm 3 \mathrm{~Hz}$ lik kayma gözlenmiştir. Elde edilen toplu sonuçlar Şekil 2'de sunulmuştur. QCM sensör yüzeyinde aldehit oluşumu sağlandıktan sonra kristal oda sıcaklığında $0,1 \mathrm{mg} / \mathrm{mL}$ derişiminde BSA çözeltisine pH 5 fosfat tamponuna daldırılarak 2 saat bekletilmiştir.

Yapılan bir araştırmada $0.3 \mathrm{mg} / \mathrm{ml}$ BSA derişiminin yüzey doygunluk derişimine karşılık geldiği bulunmuştur (Liu, 2003). Bu nedenle çalışmanın sunum aşamasında denenmesi düşünülen 0,2-1 $\mathrm{mg} / \mathrm{ml}$ aralığında yapılacak deneylerle doygunluk noktasının tespitinin zor olacağından BSA derişimi çok daha düşük değerlerde seçilmiştir. Daha yüksek BSA derişimleri $(0,5$ ve $1 \mathrm{mg} / \mathrm{ml}$ ) için de deneyler gerçekleştirilmiş ve okunan frekans farkı değerlerinde önemli değişimler gözlenmemiştir. Bu sonuca göre elektrot yüzeylerinin doygunluk değerine ulaştığ 1 kabul edilmiştir. BSA derişimi olarak $0,1 \mathrm{mg} / \mathrm{ml}$ yüzeyin BSA molekülü açısından zengin ve sonraki aşamalar için uygun bir yüzey olarak kabul edilmiştir. Çalışmanın devamında BSA derişimi $0,1 \mathrm{mg} / \mathrm{ml}$ olarak seçilmiş ve bütün sürekli sistem deneylerinde kullanılmıştır.

\subsection{Sürekli akış sisteminde gerçek zamanlı Homosistein tayini}

BSA immobilize edilmiş QCM sensör akış hücresine yerleştirildikten sonra 0.01 M PBS ( $\mathrm{pH}$ 7.4) çözeltisini kullanarak $100 \mu \mathrm{L} /$ dak akış hızında sürekli sistemde 4 farklı derişimde homosistein içeren çözeltilerden $100 \mu \mathrm{L}$ sürekli sisteme enjeksiyon ile verilmiştir. Çalışma kapsamında seçilen ve kullanılan homosistein derişimleri $0.01,0.05,0.1,0.5$ ve $1.0 \mu \mathrm{M}$ $(\mu \mathrm{mol} / \mathrm{L})$ dir.

Her enjeksiyon sonrası sürekli sistemin yatışkın duruma gelmesi beklenerek frekans değerleri okunmuştur (Şekil 3). Akış sırasındaki sistemin gösterdiği belli bir frekans değeri olduğundan homosistein enjeksiyonu sonrasında okunan frekans değerinden sistemin frekans değeri çıkarılarak her derişim için frekans farkları hesaplanmıştır. Hesaplanan bu frekans farkları derişimlere karşı grafiğe alınarak elde edilen noktalardan bir doğru geçirildiğinde elde edilen kalibrasyon eğrisi iyi bir doğrusallık göstermekte ve determinasyon katsayıs $(\mathbf{y}=\mathbf{8 6}, 6 x+10,05) \mathbf{R}^{2}=\mathbf{0 . 9 9 7 1}$ olarak hesaplanmıştır.

Homosistein için seçmiş olduğumuz derişim aralığının sürekli sistemde çalışılabilecek bir aralık olduğunu ifade etmiştir.

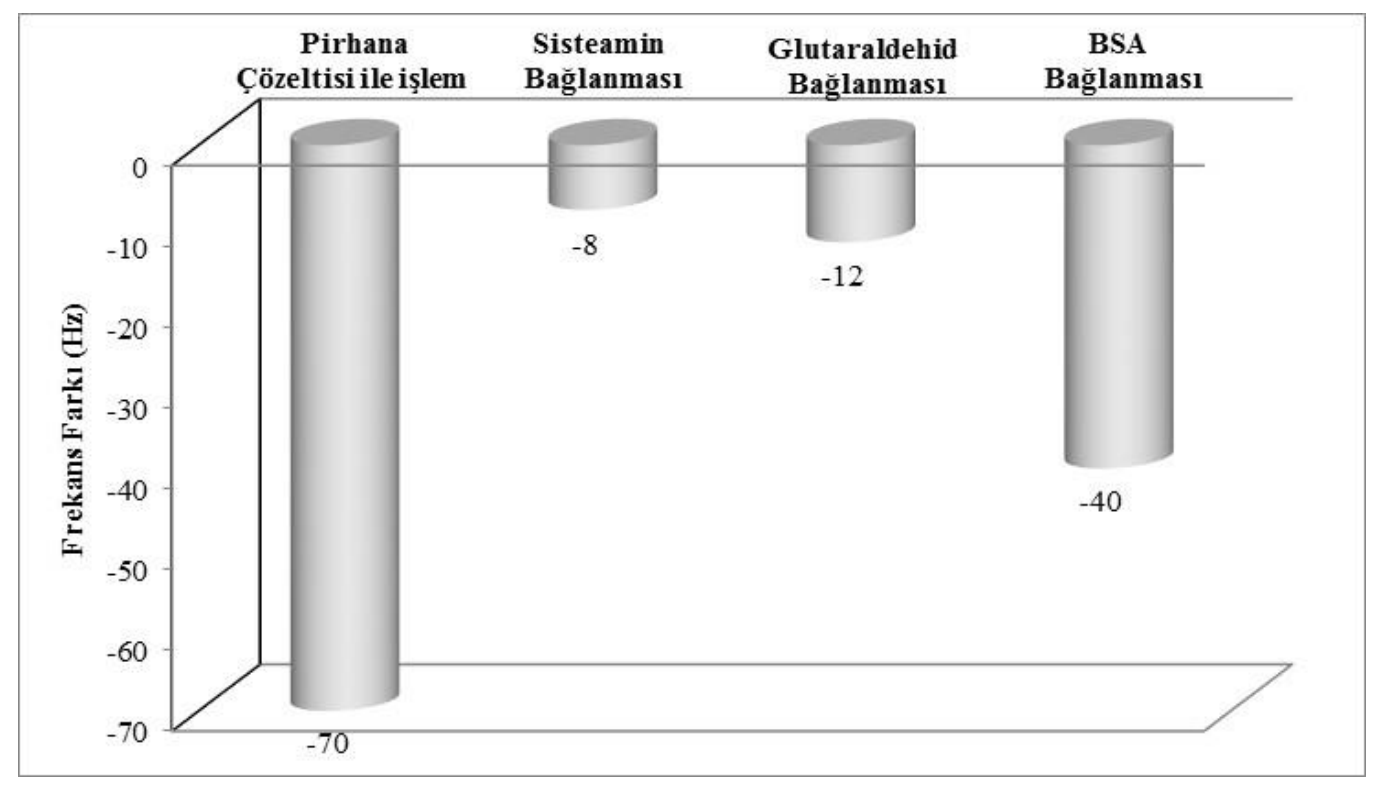

Şekil 2. Yüzey Temizliği, Sisteamin, GA ve BSA Bă̆lanması Frekans Değişim (AF) Değerleri. 


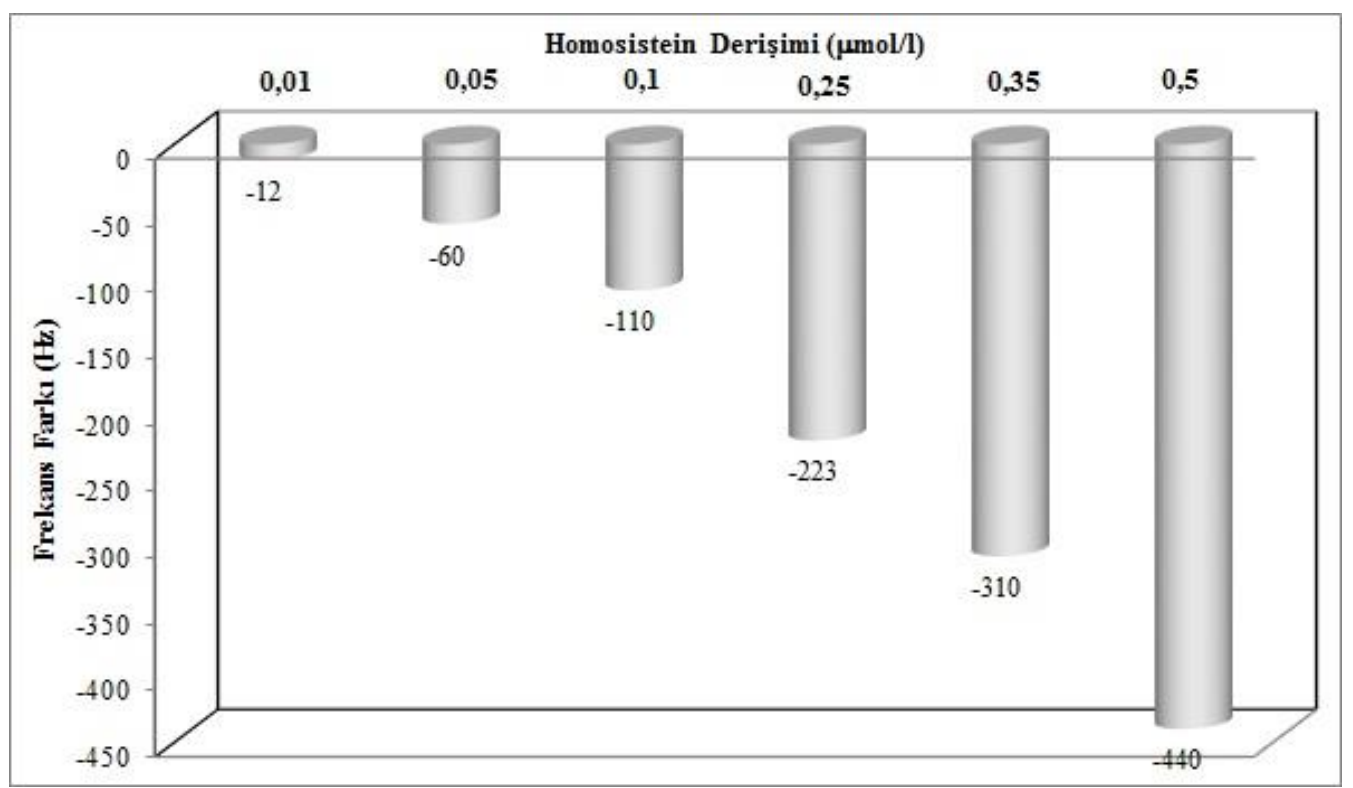

Şekil 3. Homosistein Derişiminin Frekans Değişim ( $\Delta F)$ Değerleri.

Çalışmanın bundan sonraki aşamalarında bu derişim aralığı kullanılarak sürekli sistem de gerçek zamanlı homosistein ölçümleri gerçekleştirilmiştir. Çalışmanın basmaklarına geçmeden önce sürekli sistemin verim hesab1 da gerçekleştirilmiştir.

Derişimi $0,2 \mu \mathrm{M}$ olarak hazırlanan bir homosistein çözeltisini elde edilen doğru dekleminden hesaplarsak 27,32 Hz bulunmaktadır. Aynı çözelti sürekli sisteme enjekte edildiğinde elde edilen frekans kayma değeri $27 \mathrm{~Hz}$ olarak ölçülmüştür.

\section{$27 \mathrm{~Hz} / 27,32 \mathrm{~Hz}$ x $100=\% 98,8$}

Diğer bir denemede ise derişimi $0,3 \mu \mathrm{M}$ olarak hazırlanan bir homosistein çözeltisini elde edilen doğru dekleminden hesaplarsak 35,98 Hz bulunmaktadır. Aynı çözelti sürekli sisteme enjekte edildiğinde elde edilen frekans kayma değeri $35 \mathrm{~Hz}$ olarak ölçülmüştür.
$35 \mathrm{~Hz} / 35,98 \mathrm{~Hz} \times 100=\% 97,27$

$$
\text { Ortalama verim }(98,8+97,27) / 2=\% 98,04
$$

İlk ve ikinci ölçümlerde elde değerlerin \% verim hesabı yapılıp ortalaması alındığında kalibrasyonu yapılan sürekli sistemin yaklaşık \%98 gibi yüksek bir verim ile çalıştığı bulunmuştur.

\subsection{Gerçek zamanlı ölçümlerin yapılması}

Akış sırasında homosistein enjeksiyonu ile elde edilen kalibrasyon doğrusu ve diğer ölçümler sırasında takip edilen yöntemler aşağıda belrtildiği şekilde gerçekleşmiştir. $\mathrm{Bu}$ amaçla öncelikle $0,01 \mu \mathrm{M}$ homosistein derişiminde çözelti hazırlanmış ve $100 \mu \mathrm{Lt} / \mathrm{dak}$ akış hızı olan sisteme enjekte edilmiştir. Bu enjeksiyon için öncelikle sistemin yatışkın duruma gelmesi beklenmiş (yaklaşık 1/2 saat) yatışkın durum frekansı belirlenmiş ardından $100 \mu \mathrm{Lt}$ örnek akış sistemine enjekte edilmiştir (Şekil 4.

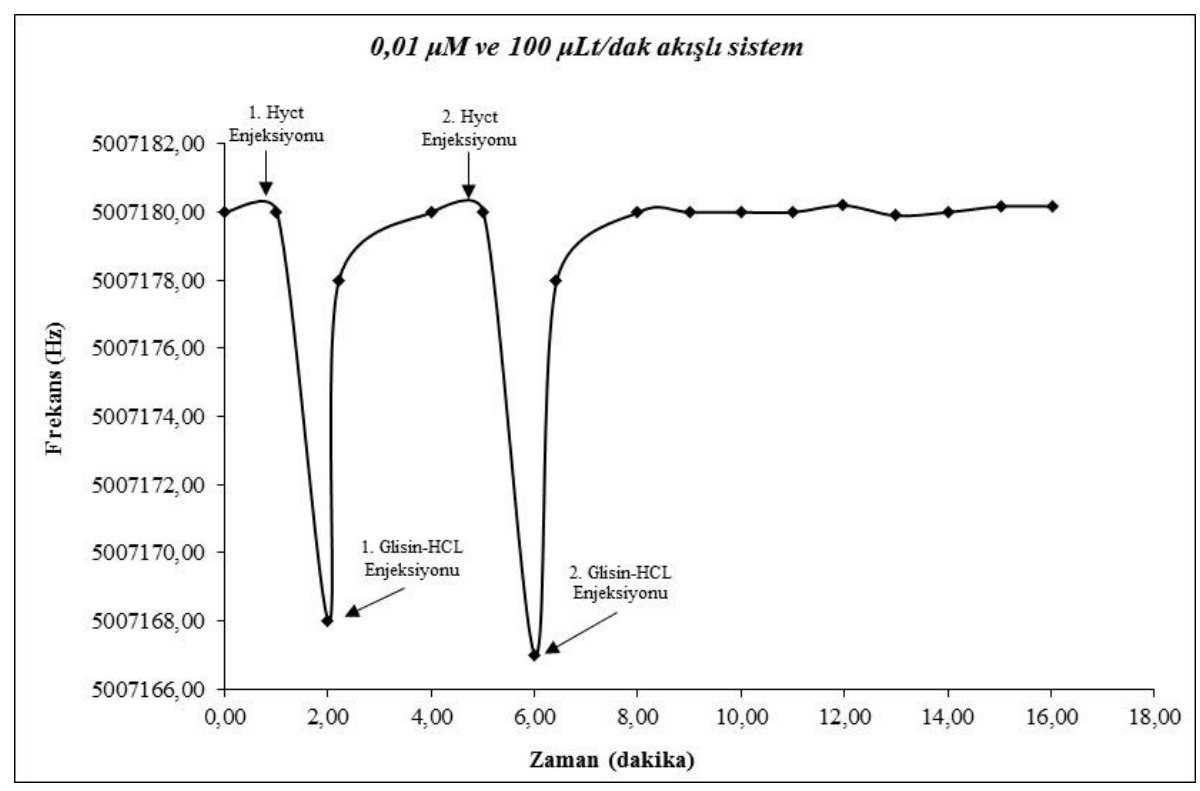

Şekil 4. 0,01 $\mu$ M homosistein derişimi için zamana karşı akış sistemindeki davranışı. 


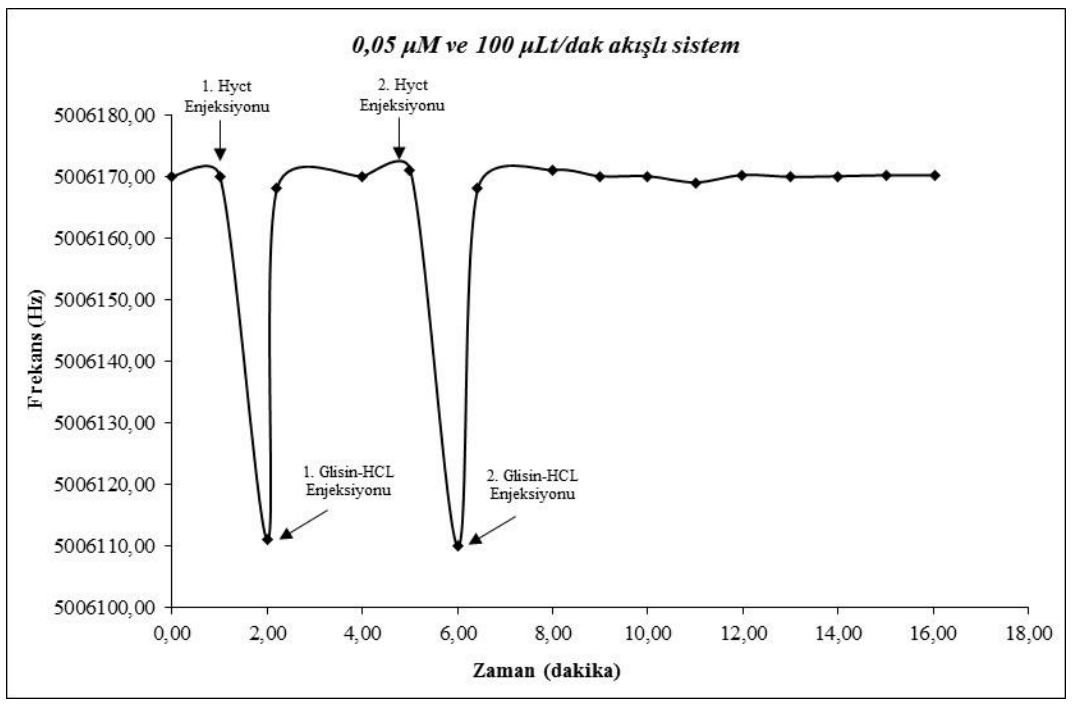

Şekil 5. 0,05 $\mu$ M homosistein derişimi için zamana karşı akış sistemindeki davranışı.

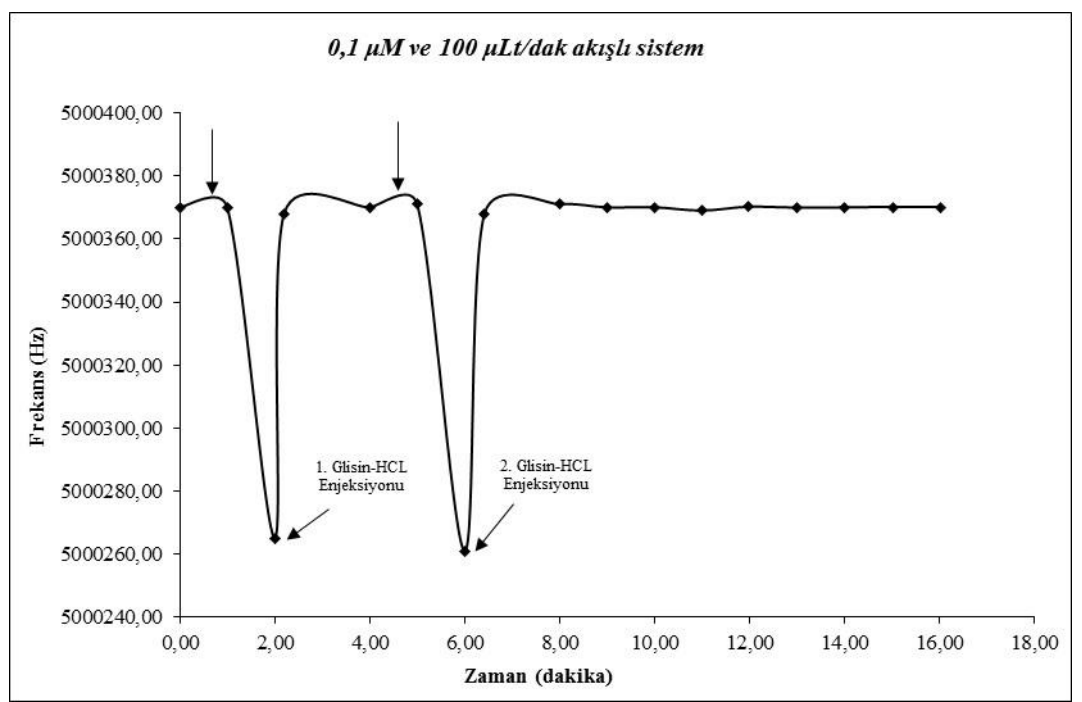

Şekil 6. 0,1 $\mu$ M homosistein derişimi için zamana karşı akış sistemindeki davranışı.

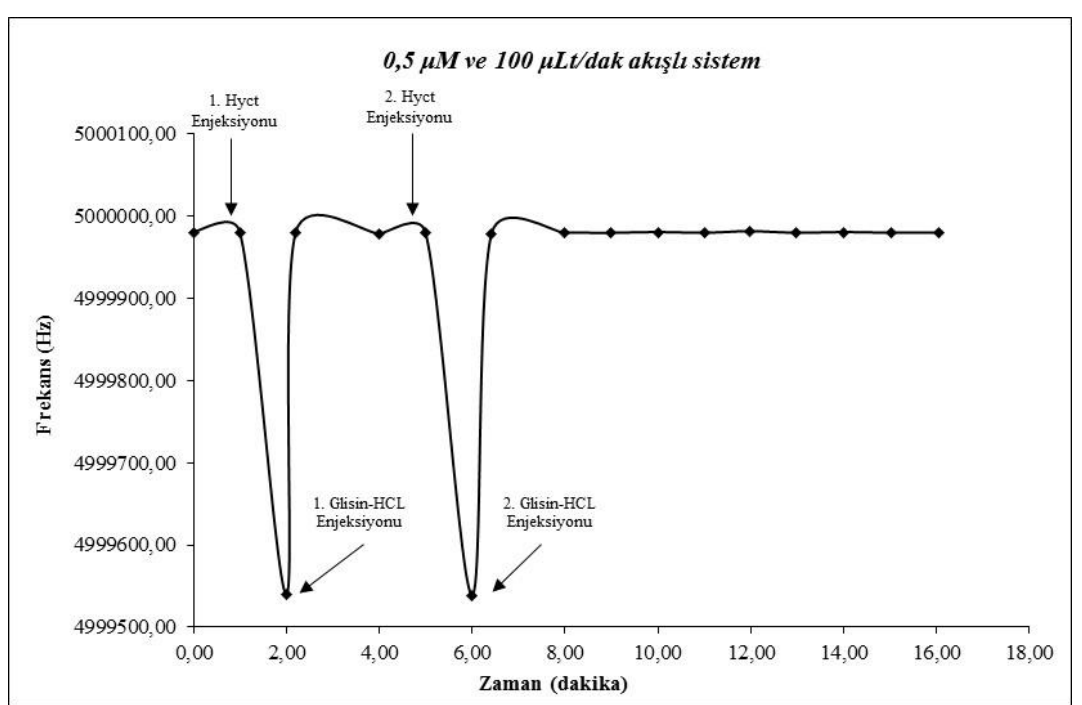

Şekil 7. 0,5 $\mu$ M homosistein derişimi için zamana karşı akış sistemindeki davranışı.

Örnek sisteme enjekte edilikten sonra frekans düşüşleri saptanmış ve daha sonra Glisin-HCl enjekte edilerek homosisteinin bağlandığı bölgelerden koparılması sağlanarak ölçülen frekans değerlerinin başlangıç noktalarına yani elektrodun yatışkın durum frekansına gelmesi beklenmiştir. Bu durum oluştuğunda ise ikinci homosistein enjeksiyonu ve ardından ikinci Glisin- $\mathrm{HCl}$ enjeksiyonu ile aynı durumların tekrarlanması sağlanmıştır. 
Çalışmanın bundan sonraki aşamalarında homosisteninin diğer derişimleri için de benzer şekilde deneyler gerçekleştirilmiştir. $0,05 \mu \mathrm{M}$ homosistein derişim için yapılan benzer çalışmada elde edilen grafik Şekil 5'de sunulmaktadır. Şekilden görüleceği gibi yatışkın durum sırasında yapılan 1 . ve 2 . homosistein enjeksiyonlarında yaklaşık $60-75 \mathrm{~Hz}$ 'lik bir frekans düşüşü gözlenmiştir. Aynı şekilde 1. ve 2. Glisin- $\mathrm{HCl}$ enjeksiyonlarında da sistemin yatışkın durum frekans değerlerine tekrar ulaşmıştır.

$0,1 \mu \mathrm{M}$ homosistein derişim için yapılan benzer çalışmada elde edilen grafik Şekil 6'da sunulmaktadır. Şekilde de yatışkın durum sirasında yapılan 1 . ve 2 . homosistein enjeksiyonlarında yaklaşık 100-110 Hz'lik bir frekans düşüşü gözlenmiştir. Aynı şekilde 1. ve 2. Glisin- $\mathrm{HCl}$ enjeksiyonlarında da sistemin yatışkın durum frekans değerlerine tekrar ulaşmıştır. 0,5 $\mu \mathrm{M}$ homosistein derişim için yapılan çalışmada ise elde edilen grafik Şekil 7'de sunulmaktadır. Şekilden de görüleceği gibi yatışkın durum sırasında yapılan 1. ve 2. homosistein enjeksiyonlarında yaklaşık 400-450 Hz'lik bir frekans düşüşü gözlenmiştir. Aynı şekilde 1. ve 2. Glisin- $\mathrm{HCl}$ enjeksiyonlarında da sistemin yatışkın durum frekans değerlerine tekrar ulaşmıştır.

Çalışmanın bu aşamasında ise gün içi ve günler arası tekrarlanabilirlik deneyleri gerçekleştirilmiştir. Çalışmanın son aşamasında seçilen bir homosistein derişimi için gün içinde ve günler arası olmak üzere deneyler gerçekleştirilmiş ve bu sayede modifiye edilen bir piezo kristal için sürekli sistemde kaç kez ölçüm yapılabildiği ve hangi hassasiyet sınırları içinde ölçümler yapıldığı araştırılmış ve bulunan sonuçlar aşağıda tartışılmıştır. Yukarıdaki deneyler sırasında elde edilen frekans fark1 $100 \mathrm{~Hz}$ dolaylarında olan $0,1 \mu \mathrm{M}$ homosistein derişim değerinde deneylere devam edilmiştir.
Aynı gün içinde farklı saatlerde yapılan deneylerden elde edilen sonuçlar Çizelge 1'de verilmiştir. Benzer deneyler yine 0,1 $\mu \mathrm{M}$ homosistein derişiminde örneklerin farklı günlerde sisteme enjekte edilerek deneylere devam edilmiştir. Farklı günlerde yapılan deneylerden elde edilen sonuçlar ise Çizelge 2'de verilmektedir.

Çizelge 1'den de görüleceği gibi aynı gün içinde 24 saate kadar ölçümler alınmış ve elde edilen frekans kayması değeri 101 $\mathrm{Hz}$ ile $113 \mathrm{~Hz}$ arasında değişen değerler elde edilmiştir. Çizelge 2 den de 120 güne kadar tekrar edilen günlerarası deney sonuçları sunulmuştur. $\mathrm{Bu}$ değerlerde yine $101 \mathrm{~Hz}$ ile $118 \mathrm{~Hz}$ arasında değişim göstermiştir. Hem gün içi hem de günlerarası gerçek zamanlı olarak incelenmiş ve insan $\operatorname{IgG}$ için en düşük değer $6.5 \times 10^{-8} \mathrm{~mol} \mathrm{~L}^{-1}$ olarak bulunmuştur (Liu, 2003, b). Histidine ve IgG arasındaki etkileşim QCM ile yine gerçek zamanlı olarak araştırıldığında insan IgG için bulunan en düşük değer $1.3 \times 10^{-7}$ mol L ${ }^{-1}$ olarak belirlenmiştir (Liu, 2003b). Sığır geçici humma virüsünün (BEFV) tespiti amacı ile yapılan bir araştırmada 5 $\mu \mathrm{g} / \mathrm{ml}$ alt tayin değerine ulaşılmıştır (Lee, 2005). Başka bir araştırmaa tasarlanan elektrokimyasal aptasensör ile $1 \times 10^{-8} \mathrm{~mol} / \mathrm{L}$ tayin limiti elde edildiği rapor edilmiştir. QCM-temelli homosistein analizinde Çizelge 3'te ulaşılabilen en düşük tayin değerleri ve ilgili çalışmalar açıklanmıştır.

Çizelge 1. Gün içi tekrarlanabilirlik deneyleri.

\begin{tabular}{|c|c|c|c|c|c|c|c|c|c|c|c|c|c|}
\hline & \multicolumn{13}{|c|}{ Tekrar aralıkları } \\
\hline Saat & 1. & 2. & 3. & 4. & 5. & 6. & 7. & 8. & 9. & 10. & 11. & 12. & 24. \\
\hline Frekans Farkı (Hz) & 102 & 105 & 110 & 112 & 101 & 103 & 108 & 109 & 101 & 113 & 111 & 102 & 105 \\
\hline
\end{tabular}

Çizelge 2. Günler arası tekrarlanabilirlik deneyleri.

\begin{tabular}{|c|c|c|c|c|c|c|c|c|c|c|c|c|c|}
\hline & \multicolumn{13}{|c|}{ Tekrar aralıkları } \\
\hline Gün & 1. & 2. & 3. & 4. & 5. & 6. & 7. & 15. & 30. & 45. & 60. & 90. & 120. \\
\hline Frekans Farkı (Hz) & 112 & 115 & 110 & 102 & 101 & 104 & 118 & 102 & 111 & 113 & 101 & 106 & 108 \\
\hline
\end{tabular}

Çizelge 3. Farklı çalışmalarda biyolojik moleküller için elde edilen en düşük tayin değerleri.

\begin{tabular}{|c|l|}
\hline En düşük tayin değeri & \multicolumn{1}{c|}{ Araştırma } \\
\hline $1 \times 10^{-8} \mathrm{~mol} / \mathrm{L}$ & $\begin{array}{l}\text { Homosistein tayini (BSA biyomolekülünün immobilizasyonu ile) } \\
\text { (Bu çalışma) }\end{array}$ \\
\hline $1 \times 10^{-7} \mathrm{~mol} / \mathrm{L}$ & $\begin{array}{l}\text { Homosistein tayini (Homosistein antibadi immobilizasyonu ile) } \\
\text { (Ayhan, 2020) }\end{array}$ \\
\hline $1 \times 10^{-8} \mathrm{~mol} / \mathrm{L}$ & $\begin{array}{l}\text { Elektrokimyasal Altın nanopartikül-aptamer ile Homosistein tayini } \\
\text { (Beitollahi, 2020) }\end{array}$ \\
\hline $6,5 \times 10^{-8} \mathrm{~mol} / \mathrm{L}$ & İnsan IgG tayini Liu, 2003a \\
\hline $1 \times 10^{-6} \mathrm{~mol} / \mathrm{L}$ & Human Hcy ELISA Kit \\
\hline $1,3 \times 10-7 \mathrm{~mol} / \mathrm{L}$ & Histidin-IgG etkileşimi Liu,2003b \\
\hline $5 \mu \mathrm{g} / \mathrm{mL}$ & Siğır geçici humma virüsü Lee, 2005 \\
\hline
\end{tabular}




\section{Sonuç}

Elde edilen bu sonuçlara genel olarak bakılacak ve yorumlanacak olursa Homosisteinin sürekli sistemde tayini için elde edilen kalibrasyon grafiği içinde kalan tüm derişimler için gerçek zamanlı ölçüm sistemi olarak yapılan ve uygulanan piezo kristalli sensör sistemi başarıya ulaşmıştır. Çalışmada Homosistein için en düşük tayin edilebilir değer $1 \times 10^{-8} \mathrm{~mol} \mathrm{~L}^{-1}$ (10 nanoM) olarak bulunmuştur.

Sunulan bu çalışmada elde edilen sonuçlar göstermektedir ki kuartz kristal mikroterazinin kullanıldığı sürekli akış sistemi ile homosistein tayini için yüksek hassasiyette bir NANOBIYYOSENSÖR yapmak mümkündür. $\mathrm{Bu}$ nedenle halen kullanılan sistemler yanında bir başka yöntem olarak da ele alınabilir. Elde edilen veriler daha sonraki bilimsel çalışmalar için de yol gösterecek niteliktedir.

\section{Teşekkür}

$\mathrm{Bu}$ çalışma TÜBİTAK tarafindan $108 \mathrm{~T} 642$ nolu proje ile maddi olarak desteklenmiştir.

\section{Kaynakça}

Andersson, M., Andersson, J., Sellborn, A., Berglin, M., Nilsson, B., Elwing, H., Quartz crystal microbalance-with dissipation monitoring (QCM-D) for real time measurements of blood coagulation density and immune complement activation on artificial surfaces. Biosensors and Bioelectronics, 21, 79-86, (2005)

Ayhan, F., Kaya, G., Ayhan,H., Homosistein-BSA-afinite temelli biyosensor tasarımı. Türk Biyokimya Dergisi, 39(3):383396, (2014).

Beitollahi, H., Zaimbashi, R., Mahani, M. T., Tajik, S., A labelfree aptasensor for highly sensitive detection of homocysteine based on gold nanoparticles. Bioelectrochemistry 134, 107497, (2020).

Bereli, N., Çimen, D., Hüseynli, S., Denizli, A., Detection of amoxicillin residues in egg extract with a molecularly imprinted polymer on gold microchip using surface plasmon resonance and quartz crystal microbalance methods. Journal of Food Science, Vol. 85, Iss. 12, (2020).

Bunde, R.L., Jarvi, E.J., Rosentreter, J.J., Piezo electric quartz crystal biosensor, Talanta, 46, 1223-36, (1998).

Frantzen, F, Faaren, AL, Alfheim, I, Nordhei, AK, Enzyme conversion immunoassay for determining total homocysteine in plasma or serum, Clinical Chemistry, 44, 311-6, (1998).

Herne, T. M., Tarlov, M. J., Characterization of DNA Probes Immobilized on Gold Surfaces, Journal of American Chemical Society, 119, 8916-20, (1997).

Horst, D. J., Junior, P. P. de A., Duvoisin, C. A., Vieira, R. de A., Fabrication of Conductive Filaments for 3D-printing: Polymer Nanocomposites. 10, 6, , 6577 - 6586, (2020).

Hou K.C., Zaniewski R. and Roy S., Protein A immobilized affinity cartridge for immunoglobulin purification, Biotechnology and Applied Biochemistry, 13, 257-62, (1991).

Imai, K., Toyo'oka, T., Fluorometric Assay of Thiols with Fluorobenzoxadiazoles, Methods in Enzymology, 143, 67-75, (1987).
Jacobsen, D.W., Gatautis, V.J., Green R, Determination of Plasma Homocysteine by High-Performance Liquid Chromatography with Fluorescence Detection, Analytical Biochemistry, 178, 208-14, (1989).

Karamollaoğlu, İ., Öktem, H. A., Mutlu, M., QCM-based DNA biosensor for detection of genetically modified organisms (GMOs) Biochemical Engineering Journal 44, 142-150, (2009).

Karousos, N.G., Aouabdi, S., Way, A.S., Reddy SM, Quartz crystal microbalance determination of organophosphorus and carbamate pesticides, Analytica Chimica Acta, 469, 189-96, (2002).

Krijt, J., Vackova M, Kozıch, V. Measurement of homocysteine and other aminothiols in plasma: advantages of using tris(2carboxyethyl)phosphine as reductant compared with tri-nbuthylphosphine, Clinical Chemistry, 47, 10, 1821-8, (2001).

Laibinis, P. E., Whitesides, G. M., Allara, D. L., Tao, Y.-T., Parikh, A. N., Nuzzo, R. G., Monolayers of $n$-Alkanethiols on the Coinage Metal Surfaces, $\mathrm{Cu}, \mathrm{Ag}, \mathrm{Au}$, Journal of American Chemical Society, 113, 7152-7167, (1991).

Lee, Y.G., Chang, K.S., Application of a flow type quartz crystal microbalance immunosensor for real time determination of cattle bovine ephemeral fever virus in liquid, Talanta, 65, 1335-1342, (2005).

Likogianni, V., Janel, N., Ledru, A., Beaune, P., Thiol compounds metabolism in mice, rats and humans: Comparative study and potential explanation of rodents protection against vascular diseases, Clinical Chimica Acta, 372, 140-6, (2006).

Liu, Y., Yu, X., Zhao, R., Shangguan, D., Li, Y., Zuyi, B., Liu, G., Real time kinetic analysis of the interaction between immunoglobulin $\mathrm{G}$ and histidine using quartz crystal biosensor in solution, Biosensors and Bioelectronics, 18, 1419-1427, (2003, a).

Liu, Y., Yu, X., Zhao, R., Shangguan, D., Li, Y., Zuyi, B., Liu, G., Quartz crystal biosensor for real-time monitoring of molecular recognition between protein and small molecular medicinal agents, Biosensors and Bioelectronics, 19, 9-19, $(2003, b)$.

Liu, Y., Zhang, W, Yu, X., Zhang, H., Zhao, R., Shangguan, D., Li, Y., Shen, B., Liu, G., Quartz crystal biosensor for realtime kinetic analysis of interaction between human TNF- $\alpha$ and monoclonal antibodies, Sensors and Actuators: B, 99, 416-24, (2004).

Liu, Y.C, Wang, C.M., Hsiung, K.P., Comparison of Different Protein Immobilization Methods on Quartz Crystal Microbalance Surface in flow Injection Immunoassay, Analytical Biochemistry, 299, 130-5, (2001).

Marx, K. A., Quartz Crystal Microbalance: A Useful Tool for Studying Thin Polymer Films and Complex Biomolecular Systems at the Solution-Surface Interface, Biomacromolecules, 4 (5), 1099 -1120, (2003).

Matthews, O.A., Shipway, A. N., Stoddart, J.F., DendrimersBranching out from curiosities into new Technologies, Progress in Polymer Science, 23, 1-56, (1998).

Ozalp, V. C., Bayramoglu, G., Erdem, Z., Arica, M. Y., Pathogen detection in complex samples by quartz crystal microbalance sensor coupled to aptamer functionalized core-shell type magnetic separation. Analytica Chimica Acta 853 533-540, (2015).

Refsum, H., Ueland, M., Svardal. A.M., Fully Automated Fluorescence Assay for Determining Total Homocysteine in Plasma, Clinical Chemistry, 35(9), 1921-7, (1989). 
Sauerbrey, G.A., Use a quartz vibrator form weight thin films on a microbalance, Z. Phys., 155, 206-210, (1959).

Shende, P., Kasture, P., Dendrimeric biosensor for detection of $E$. coli O157:H7 in diet. Biointerface Research in Applied Chemistry. 10, 2, , 5128-5131, (2020).

Tanaka, M., Mochizuki, A., Motomura, T., Shimura K, Onishi M, Okahata Y, In situ studies on protein adsorption onto a poly(2-methoxyethylacrylate) surface by a quartz crystal microbalance, Colloids and Surfaces A: Physicochemical and Engineering Aspects, 193, 145-152, (2001).

Ubbink, J.B., Assay Methods for the Measurement of Total Homocyst(e)ine in Plasma. Seminars in Thrombasis and Hemostatis, 26 (3), 233-41, (2000).

Ueland, P.M., Refsum, H., Stabler, S.P., Malinow MR, Andersson A, Allen RH. Total Homocysteine in Plasma or Serum: Methods and Clinical Applications (Review), Clinical Chemistry, 39, 1764-79, (1993).

Vester, B., Rasmussen, K., High Performance Liquid Chromatography Method for Rapid and Accurate Determination of Homocysteine in Plasma and Serum, European Journal of Clinical Chemistry and Clinical Biochemistry, 29, 549-54, (1991).

Xie, Q.; Xiang, C.; Yuan, Y.; Zhang, Y.; Nie, L. and Yao, S.; A novel dual-impedance-analysis EQCM systeminvestigation of bovine serum albumin adsorption on gold and platinum electrode surfaces. Journal of Colloid and Interface Science 262, 107-115, (2003).

Yılmaz, M., Bakhshpour, M., Göktürk I.,, Kevser Piskin A, Denizli, A., Quartz Crystal Microbalance (QCM) Based Biosensor Functionalized by HER2/neu Antibody for Breast Cancer Cell Detection. Chemosensors, 9, 80, (2021).

Zhang, H., Zhao, Rui., Chen, Z., Shangguan, D., Liu, G., QCMFIA with PGMA coating for dynamic interaction study of heparin and antithrombin III, Biosensors and Bioelectronics 21, 121-127, (2004).

Zhang, Q., Huang, Y., Zhao, R., Liu, G., Chen, Y., Determining binding sites of drugs on human serum albumin using FIAQCM. Biosensors and Bioelectronics 24, 48-54, (2008). 